\title{
Nonalcoholic fatty liver disease and hepatocellular carcinoma
}

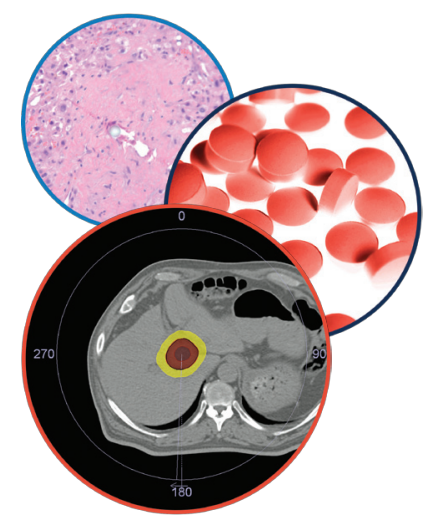

Hepatic Oncology

\author{
Stephanie Klein ${ }^{1,2} \&$ Jean-François Dufour ${ }^{*, 1,2}$
}

\section{Practice points}

- Hepatocellular carcinoma (HCC) is the third most common cause of cancer death worldwide.

- Nonalcoholic steatohepatitis (NASH) is the hepatic manifestation of the metabolic syndrome.

- NASH is a carcinogenic disease.

- HCC in the context of NASH arises in half of the cases before cirrhosis.

- Diabetes mellitus and obesity are independent risk factors for HCC.

- The intake of metformin, thiazolidinediones, aspirin or statins could reduce the risk of developing HCC.

- It is important to enroll patients at risk in a surveillance program; the precirrhotic population at risk should be better defined.

- The therapeutic management of HCC in NASH is the same than in patients with HCC due to other underlying liver diseases.

Hepatocellular carcinoma (HCC) in patients with nonalcoholic fatty liver disease is becoming more common globally. The incidence of HCC due to nonalcoholic steatohepatitis in comparison to other etiologies is increasing. This is due to the pandemic of obesity and diabetes mellitus, two important risk factors for HCC. HCC arising in this context occurs in about $40 \%$ of the cases in a liver which is not yet cirrhotic. This has implications regarding the population which should be enrolled in an HCC surveillance program and regarding the treatment options. Surgery is more frequently contemplated in patients with HCC and no cirrhosis. However, patients with nonalcoholic steatohepatitis-induced HCC have frequent co-morbidities which have to be taken into account when developing a management strategy. Interestingly, these patients are frequently on medications which have been suggested to decrease the risk to develop HCC.

First draft submitted: 30 May 2017; Accepted for publication: 22 August 2017; Published online: 30 October 2017

Hepatocellular carcinoma (HCC) is the third most common cause of cancer death worldwide, and the fifth and seventh most common cancer in men and women, respectively [1]. Moreover, liver cancer mortality, particularly as a result of HCC, is increasing in both sexes [2]. HCC mortality due to chronic hepatitis $\mathrm{C}(\mathrm{CHC})$ and $\mathrm{B}(\mathrm{CHB})$ is decreasing, whereas $\mathrm{HCC}$ mortality due to nonalcoholic fatty liver disease (NAFLD) is increasing [3].

The percentage of patients with liver cirrhosis due to $\mathrm{CHC}$ and $\mathrm{CHB}$ infections on the transplantation list is decreasing, which may be attributed to better management of patients infected with hepatitis $\mathrm{C}$ virus (HCV) and hepatitis $\mathrm{B}$ virus, as well to the introduction of powerful nucleotide analogs to treat $\mathrm{CHB}$ and the direct antiviral agents to cure $\mathrm{CHC}$. In contrast, the percentage of patients with NASH on the waiting list is increasing [4]. Currently, NASH is the second leading etiology of patients listed for transplantation because of HCC [5], and from 2004 to 2015 the number

'Department of Clinical Research, Hepatology, University of Bern, Bern, Switzerland

${ }^{2}$ University Clinic for Visceral Surgery \& Medicine, Inselspital Bern, Bern, Switzerland

*Author for correspondence: Tel.: +41 31632 26 95; Fax: +41 31632 97 65; jf.dufour@insel.ch

\section{KEYWORDS}

- diabetes mellitus • obesity

- resection 
of NASH patients on the transplantation list in the USA has almost tripled [6]. The burden of patients with NASH, NASH-cirrhosis and its associated complications is also growing [7]. In the coming years, NASH is likely to become the leading cause of cirrhosis and HCC.

The pathogenesis of HCC arising in the context of NAFLD as underlying liver disease is not yet well understood [8]. The molecular classifications of HCCs did not provide a signature pathognomonic for HCC in NAFLD/NASH [9]. Nevertheless, several features seem to be particularly important in this hepatocarcinogenic process (Figure 1): the insulin resistance which is associated with high levels of insulin which is an important growth factor; the dysfunction of the Akt/mTOR pathway which bridges metabolism control with cell proliferation; the oxidative stress; and a dysbiosis with quantitative and qualitative changes of the gut microbiota $[10,8,11,9]$.

Metabolic syndrome as a risk factor for developing HCC

The incidence and prevalence of metabolic syndrome with components like diabetes mellitus and obesity are increasing worldwide. There is a close association between NASH and metabolic syndrome and, therefore, the incidence and prevalence of NASH are also increasing on a global scale. Surveying the patients who were discussed at the tumor board from 2000 to 2010, Dyson et al. found that the prevalence of metabolic risk factors in patients with HCC is exploding for 0-66\% [12].

In a large case-control study performed with the Surveillance, Epidemiology and End ResultsMedicare database the proportion of patients with metabolic syndrome was significantly elevated in patients with $\mathrm{HCC}$ compared with those without HCC [13]. Another case-control study reported that accumulation of the components of the metabolic syndrome is associated with a higher HCC risk. HCC risk was almost fourfold higher with greater than or equal to two components of metabolic syndrome, and for patients without $\mathrm{CHB}$ or $\mathrm{CHC}, \mathrm{HCC}$ risk was more than sixfold higher [14]. Moreover, obesity and diabetes mellitus seem to be independent risk factors for HCC in patients with chronic viral hepatitis [15].

\section{- Diabetes mellitus: an independent risk factor}

Almost 20 years ago, Adami et al. suggested a relationship between diabetes mellitus and the risk of developing HCC [16]. Since then, a large body of evidence has confirmed that diabetes mellitus is an independent risk factor for HCC (Table 1). In a cohort study of 173,643 veteran male patients, who were discharged with a new diagnosis of diabetes mellitus, and using three matched patients without diabetes for comparison, El-Serag et al. demonstrated that diabetes led to significant time-dependent increased risk of developing HCC, independent of viral hepatitis and demographic characteristics [17]. Hassan et al. also found an association between longer duration of diabetes and the risk of developing HCC [18]. In line with this observation, the incidence of HCC in patients with diabetes mellitus was shown to almost double in a case-control study. Patients with diabetes were shown to have a two- to threefold increased risk of HCC regardless of the etiology of the liver diseases [19]. The Singapore Chinese Health Study reported similar findings in a cohort of 63,257 middle-aged and older Chinese people (men and women), in which an association between diabetes mellitus and nonviral HCC was demonstrated (hazard ratio [HR]: 2.14; 95\% CI [16]: 1.69-2.71) [20].

There are also reports on the association between diabetes mellitus and the risk of developing HCC in patients with viral hepatitis. In a cohort study that included 541 diabetes patients with $\mathrm{CHC}$ and cirrhosis, there was a threefold increased risk of developing HCC in the group of patients with an Ishak score over six in comparison with the overall cohort (HR: $3.28 ; 95 \%$ CI: 1.35-7.97) [21]. In a case-control study, treatment-naive patients with $\mathrm{CHC}$ and HCC were compared with those without HCC for prevalence of diabetes, which revealed a twofold risk of developing $\mathrm{HCC}$ in those with diabetes (HR: 1.8; 95\% CI: 1.17-2.75) [22]. A systematic review of $\mathrm{CHC}$ patients indicated that glucose abnormalities are associated with $\mathrm{CHC}$ and lead to negative outcome of liver disease [23].

Complicating the interpretation of these results is the fact that HCV directly interferes with insulin-signaling pathways resulting in insulin resistance [24]. Consequently, diabetes mellitus cannot be considered an independent risk factor for HCC in patients infected with HCV.

Two interesting findings were reported in a review based on 18 studies; first, diabetes is an independent risk factor of developing HCC, regardless of geographic location, alcohol 


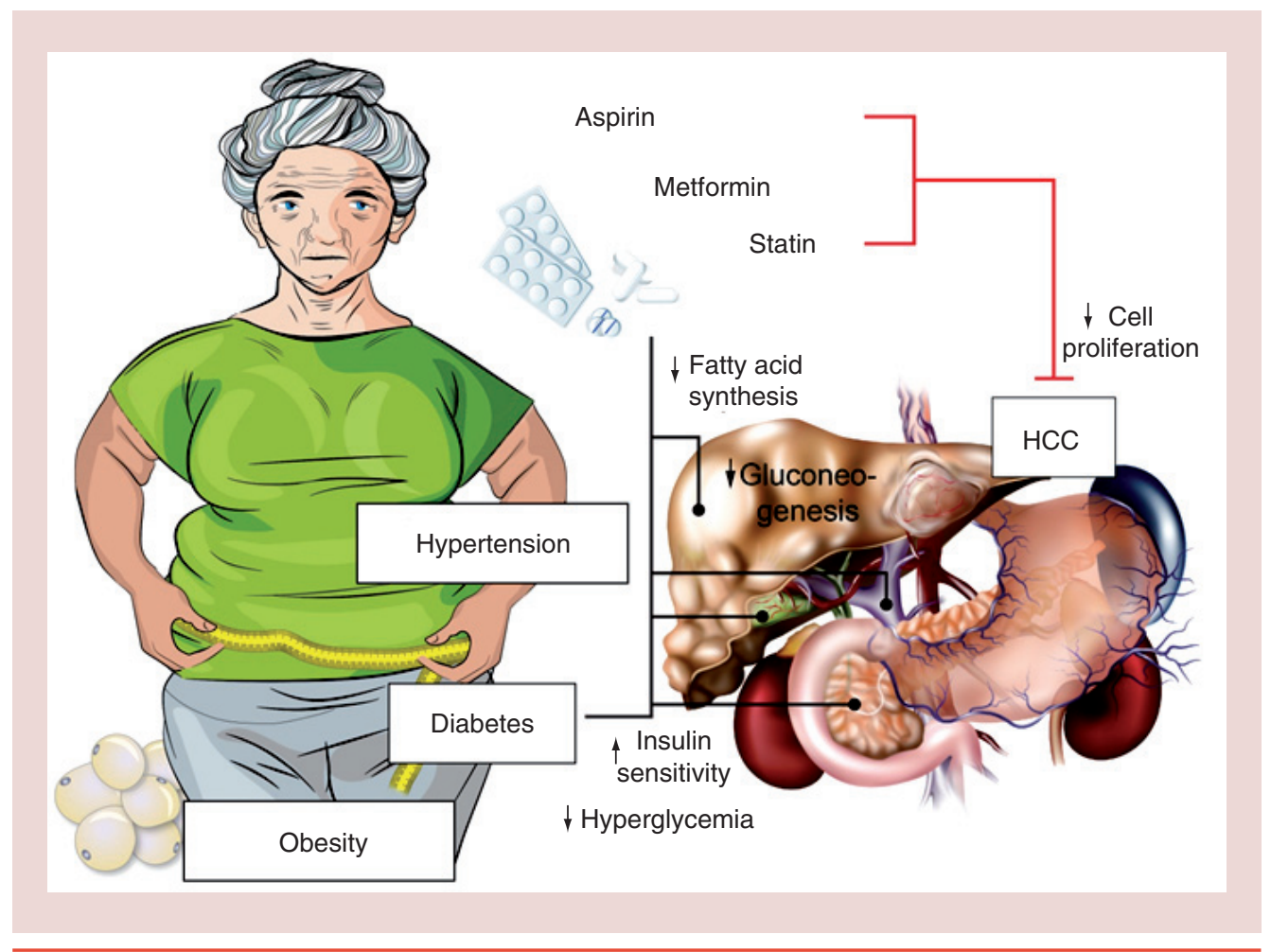

Figure 1. Clinical characteristics of a hepatocellular carcinoma in the context of nonalcoholic steatohepatitis in an older woman with arterial hypertension, obesity and diabetes mellitus. She has a large infiltrative HCC in a steatotic, noncirrhotic liver. Her risk for HCC is mitigated by her medication with metformin, statin and aspirin.

HCC: Hepatocellular carcinoma.

consumption, history of cirrhosis and viral hepatitis; and second, there is higher mortality in patients with diabetes and HCC (summary relative risk [RR]: 1.56; 95\% CI: 1.30-1.87) [25]. The association of higher mortality with diabetes and HCC was confirmed in a prospective cohort study, whereby higher mortality was shown in patients with diabetes and HCC with low Barcelona Liver Cancer Center stage, (which is based on the patient's performance status, the gravity of the cirrhosis assessed by the ChildPugh score and the tumor burden) (0, A, B) [26]. It could be speculated from these findings that treating diabetes mellitus may reduce the risk of HCC and, in turn, reduce mortality. This is particularly relevant for patients with NAFLD and metabolic syndrome who accumulate risk factors for HCC.

\section{- Obesity: an independent risk factor}

More than 20 years ago, Moller et al. observed an association between obesity and cancer. In a cohort of 43,965 obese individuals, the risk of developing cancer was increased to above
$16 \%$ compared with those who were not obese; the risk was particularly high for cancers of the esophagus and the liver [27]. Another study confirmed that obese men have an increased risk of developing several major cancers, including primary liver cancer [28]. A Canadian case-control study reported that a BMI $>25 \mathrm{~kg} / \mathrm{m}^{2}$ represented a 1.34-fold risk for overall cancer (odds ratio [OR]: 1.34 ; 95\% CI: $1.32-1.96)$ [29]. This association between being overweight and cancer has also been observed in Asia [30]. A Korean, prospective cohort study investigated if there was a gender difference for developing cancer in obese patients. The risk of developing cancer was elevated in both obese men (HR: 1.63; 95\% CI: $1.27-2.10)$ and obese women (HR: 1.39; 95\% CI: 1.00-1.94) [31]. In a systematic review, an association of common and less common malignancies with an elevated BMI was found to be independent of geographic regions [32].

Numerous studies have found an association between obesity and the risk of developing HCC (Table 2). In patients with liver cirrhosis, 
Table 1. Studies showing the elevated risk of hepatocellular carcinoma with diabetes mellitus.

\begin{tabular}{|c|c|c|c|c|}
\hline $\begin{array}{l}\text { Study } \\
\text { (year) }\end{array}$ & Design & Population & $\begin{array}{l}\text { Number of } \\
\text { patients with } \\
\text { HCC/diabetes }\end{array}$ & Key finding \\
\hline $\begin{array}{l}\text { Adami et al. } \\
\text { (1996) }\end{array}$ & $\begin{array}{l}\text { Population- } \\
\text { based cohort }\end{array}$ & $\begin{array}{l}\text { - } \mathrm{n}=153,852 \\
\text { - Swedish in patient register } \\
\text { - Hospital discharged diagnosis of diabetes } \\
\text { in the period from } 1965 \text { through } 1983 \\
\text { - until } 1989\end{array}$ & $533 / 153,852$ & $\begin{array}{l}\text { Risk of HCC } \\
\text { SIRs: } 4.1 ; 95 \% \text { Cl: } 3.8-4.5 \\
\text { Men higher (SIR: } 4.7 ; 95 \% \text { Cl: } 4.2-5.2 \text { ) } \\
\text { Than in women (SIR: } 3.4 ; 95 \% \text { Cl: } 2.9-3.9 \text { ) }\end{array}$ \\
\hline $\begin{array}{l}\text { Davila et al. } \\
\text { (2005) }\end{array}$ & Case-control & $\begin{array}{l}\text { - } \mathrm{n}=8244 \\
\text { Surveillance Epidemiology and En-Results } \\
\text { program (SEER) Medicare-linked database } \\
\text { - 1994-1999 }\end{array}$ & $2061 / 2090$ & $\begin{array}{l}\text { Risk of HCC diabetes vs control } \\
\mathrm{OR}_{\text {adj }}: 2.87 ; 95 \% \mathrm{Cl}: 2.49-3.3\end{array}$ \\
\hline $\begin{array}{l}\text { El- } \\
\text { Serag et al. } \\
(2004)\end{array}$ & $\begin{array}{l}\text { Retrospective, } \\
\text { case-control }\end{array}$ & $\begin{array}{l}\text { - } \mathrm{n}=824,263 \\
\text { Hospital discharge diagnosis of diabetes } \\
\text { between } 1985 \text { and } 1990 \\
\text { - Department of Veterans Affairs, Texas } \\
\text { - Until } 2000\end{array}$ & $832 / 173,643$ & $\begin{array}{l}\text { Risk of HCC diabetes vs control } \\
\text { HR: } 2.16 ; 95 \% \mathrm{Cl}: 1.86-2.52 \\
\mathrm{p}<0.0001\end{array}$ \\
\hline $\begin{array}{l}\text { Hassan et al. } \\
(2010)\end{array}$ & $\begin{array}{l}\text { Case-control } \\
\text { study }\end{array}$ & $\begin{array}{l}\text { - } \mathrm{n}=1524 \\
\text { January } 2000 \text { through July 2008, at the } \\
\text { University of Texas MD Anderson Cancer } \\
\text { Center }\end{array}$ & $420 / 255$ & $\begin{array}{l}\text { Risk of } \mathrm{HCC} \text { in diabetes } \\
\text { OR: } 4.2 ; 95 \% \mathrm{Cl}: 3.0-5.9 \\
\text { Duration of DM: } 2-5 \text { years compared with } \\
6-10 \text { years, OR: } 1.8 ; 95 \% \mathrm{Cl}: 0.8-4.1 \\
\text { Duration of DM } 2-5 \text { years compared } \\
\text { with >10 years, OR: } 2.2 ; 95 \% \mathrm{Cl}: 1.2-4.8\end{array}$ \\
\hline $\begin{array}{l}\text { Koh et al. } \\
\text { (2013) }\end{array}$ & $\begin{array}{l}\text { Prospective } \\
\text { cohort }\end{array}$ & $\begin{array}{l}\text { - } n=6,335,797 \\
\text { Chinese health study } \\
\text { 1993-1998 }\end{array}$ & $499 / 5469$ & $\begin{array}{l}\text { Risk of HCC diabetes vs nondiabetes } \\
\text { HR: } 2.14 ; 95 \% \mathrm{Cl}: 1.69-2.7\end{array}$ \\
\hline $\begin{array}{l}\text { Li et al. } \\
\text { (2017) }\end{array}$ & Case-control & $\begin{array}{l}\text { - } \mathrm{n}=817 \\
\text { Patients hospitalized at The First Hospital } \\
\text { of Jilin University in China } \\
\text { - } 2005-2016\end{array}$ & $300 / 112$ & $\begin{array}{l}\text { Risk of HCC diabetes vs control } \\
\text { OR }_{\text {adj }}: 1.80 ; 95 \% \mathrm{Cl}: 1.17-2.75\end{array}$ \\
\hline $\begin{array}{l}\text { Veldt et al. } \\
\text { (2008) }\end{array}$ & Cohort & $\begin{array}{l}\text { - } \mathrm{n}=541 \\
\text { Patient with DM and hepatitis C advanced } \\
\text { fibroses or cirrhosis } \\
\text { - Five large hepatology units in Europe and } \\
\text { Canada } \\
\text { - } 1990-2003\end{array}$ & $38 / 85$ & $\begin{array}{l}\text { Risk for HCC diabetes vs nondiabetes in } \\
\text { patients with ISHAK score } 6 \\
\text { HR: } 3.28 ; 95 \% \text { Cl: } 1.35-7.97 \\
p=0.009\end{array}$ \\
\hline $\begin{array}{l}\text { Wang et al. } \\
(2012)\end{array}$ & $\begin{array}{l}\text { Systemic } \\
\text { review and } \\
\text { meta-analysis }\end{array}$ & $\begin{array}{l}\text { - Medline from } 1 \text { January } 1966 \text { and EMBASE } \\
\text { from } 1 \text { January 1974, through } 31 \text { July } 2010 \\
\text { - } 25 \text { cohort studies }\end{array}$ & $-/-$ & $\begin{array}{l}18 \text { studies } \\
\text { DM was associated with an increased } \\
\text { incidence of HCC } \\
\text { SRRs: } 52.01 ; 95 \% \text { Cl: } 1.61-2.51\end{array}$ \\
\hline
\end{tabular}

the risk of developing an HCC was significantly elevated in cases of obesity in patients alcoholic steatohepatitis (OR: 3.2; 95\% CI: 1.5-6.6) and in patients with cryptogenic cirrhosis (OR: 11.1; 95\% CI: 1.5-87.4) [33]. In a prospective case-control study, one group of patients with cirrhosis and HCC were compared with a group of patients with cirrhosis but without HCC and also to a group with patients with any liver disease and without cirrhosis.
This work revealed that patients with cirrhosis and obesity have a fourfold increased risk of developing HCC compared with cirrhotic patients of normal weight (OR: 4.3 ; $95 \% \mathrm{CI}$ : 2.1-8.4). The HCC risk was further increased in obese patients with cirrhosis compared with those without any liver disease (OR: 47.8; 95\% CI: 9.6-74.5) [34]. In an Italian case-control study of 185 patients with HCC and 404 controls, a BMI $>30 \mathrm{~kg} / \mathrm{m}^{2}$ almost doubled the 
risk of HCC compared with BMI $\leq 30 \mathrm{~kg} / \mathrm{m}^{2}$ (OR: 1.9; 95\% CI: 0.9-3.9) [35]. The HCC risk is also elevated in those with BMI above $25 \mathrm{~kg} / \mathrm{m}^{2}$, as demonstrated by Ohishi et al [36]. The association between HCC and obesity has also been reported in a review of several cohort studies [37].

A particularly interesting point is that HCC might be influenced by the type of fat involved. Visceral fat was reported to be an independent risk factor for HCC recurrence after curative treatment in patients with suspected NASH (RR: 1.08 per $1 \mathrm{~cm}^{2}$ of visceral fat) [38]. Another point of interest is the age of onset of adiposity. Based on a large cohort of Danish children who were followed up to adulthood, Berentzen et al. reported that a higher BMI in childhood increased the risk of primary liver cancer [39]. In a prospective, multicenter cohort study of European countries, Schlesinger $e t a l$. examined if there is an association between weight gain in adulthood and the risk of liver cancer. Indeed, they showed that the risk of HCC was increased in people who were overweight during their childhood (RR: 2.48 ; 95\% CI: 1.49-4.13) [40]. In another hospital-based case-control study, it has been shown that obesity in early adulthood increased the risk of HCC overall (OR: 2.6; 95\% CI: 1.4-4.4), and also in men (OR: $2.3 ; 95 \%$ CI: $1.2-4.4$ ) and women (OR: 3.6; 95\% CI: 1.5-8.9). Furthermore, the earlier the elevation of BMI in adulthood, the earlier HCC develops [41]. In a Swedish study, it was observed that not only was HCC risk increased due to weight gain in late adolescence, but also the risk of severe liver disease was generally increased [42]. In addition, there is also evidence for a higher risk of death due to cancer in obese patients. A prospective cohort study from the American Cancer Society, which included American patients from the Cancer Prevention Study II, demonstrated an association between cancer death and obesity, in which the cancer mortality rate in overweight men was $52 \%$ higher than in those of normal weight; in women it was $62 \%$ higher [43]. The increased risk of cancer death, including liver cancer, due to obesity was also observed in a UK cohort [44]. Obesity is not only an independent risk factor for HCC; it also increases the risk of death due to HCC. Age also has an impact, in that the younger the patients are when BMI is elevated, the earlier HCC develops.
Differences between patients with HCC due to NASH \& due to other underlying liver diseases

Presentation of patients with HCC due to NASH differs from the presentation of patients with HCC due to other etiologies. Most patients with NASH and HCC present with comorbidities like heart diseases, diabetes, arterial hypertension and other diseases linked to metabolic syndrome. One important feature is that patients with HCC due to NASH present frequently without cirrhosis. A recent review also suggested that 15\% of patients with HCC due to NASH presented without cirrhosis at the time of diagnosis [45]. Furthermore, $50-64 \%$ of the cases of HCC due to NASH occur in noncirrhotic liver [46,47]. Stage of HCC also differs in NASH patients. It was found that the volume of the tumor in NASH patients without cirrhosis is larger at the time of diagnosis compared with NASH patients with cirrhosis, which is likely to be due to the absence of screening in noncirrhotic patients [45]. Findings from a large, Italian, retrospective case-control study indicated that not only is volume of HCC in patients with NASH bigger than in patients with HCC due to CHC, but also that the HCC in the group of NASH patients presents with an infiltrative pattern of growth more often than in the group of $\mathrm{CHC}$ patients [46].

Additional interesting clinical features of NASH patients with HCC are their age and survival prospects. In a cohort from the Surveillance, Epidemiology and End ResultsMedicare-linked database (2004-2009), it was found that patients with HCC due to NASH were older, had shorter survival and had more heart disease compared with patients with HCC due to other underlying liver diseases [48].

\section{Screening for HCC in NASH patients}

Guidelines recommend enrolling NASH patients with cirrhosis in a surveillance program to perform bi-annually a liver sonography as a screening test. Cirrhotic patients with NASH can be difficult to screen effectively with sonography. These patients are often obese and the quality of the hepatic ultrasound can be suboptimal. For these patients, there is often the need to escalate to a CT scan. The situation becomes even trickier for the patients with NASH who develop HCC before developing cirrhosis. How can these patients be screened? Simple stratification into two categories is needed for these patients, that is, those who might benefit from 
Table 2. Studies showing the elevated risk of hepatocellular carcinoma with obesity.

\begin{tabular}{|c|c|c|c|c|}
\hline Study (year) & Design & Population & $\begin{array}{l}\text { Number of } \\
\text { patients with } \\
\text { HCC/obesity }\end{array}$ & Key findings \\
\hline $\begin{array}{l}\text { Moller et al. } \\
\text { (1994) }\end{array}$ & Cohort & $\begin{array}{l}\text { - } n=43,965 \\
\text { Discharge registrations from Danish } \\
\text { hospitals }\end{array}$ & $58 / 43,965$ & $\begin{array}{l}\text { Elevated risk of cancer in obese people } \\
\text { Overall incidence of cancer was increased by } 16 \% \\
\text { Liver cancer } \mathrm{RR}=1.9\end{array}$ \\
\hline $\begin{array}{l}\text { Jee et al. } \\
(2008)\end{array}$ & $\begin{array}{l}\text { Prospective } \\
\text { cohort }\end{array}$ & $\begin{array}{l}\text { - } \mathrm{n}=1,213,829 \\
\text { Insured by the National Health } \\
\text { Insurance Corporation } \\
\text { - } 1992-1995\end{array}$ & 8759/- & $\begin{array}{l}\text { Elevated risk of cancer in obese men with } \mathrm{BMI}>30 \\
\mathrm{~kg} / \mathrm{m}^{2} \\
\text { HR: } 1.3995 \% ; \mathrm{Cl}: 1.00-1.94\end{array}$ \\
\hline $\begin{array}{l}\text { Nair et al. } \\
(2002)\end{array}$ & Cohort & $\begin{array}{l}\text { - } n=19,271 \\
\text { United Network of Organ Sharing } \\
\text { examined explanted liver for HCC } \\
\text { - } 1991-2000\end{array}$ & $659 / 5358$ & $\begin{array}{l}\text { Obesity as risk factor of HCC vs nonobesity } \\
\text { Patients with alcoholic cirrhosis OR: } 3.2 ; 95 \% \mathrm{Cl}: 1.5- \\
6.6 ; \mathrm{p}=0.002 \\
\text { Patients with cryptogenic cirrhosis } \\
\text { OR: } 11.1 ; 95 \% \mathrm{Cl}: 1.5-87.4 ; \mathrm{p}=0.02\end{array}$ \\
\hline $\begin{array}{l}\text { Marrero et al. } \\
(2005)\end{array}$ & $\begin{array}{l}\text { Prospective } \\
\text { case-control }\end{array}$ & $\begin{array}{l}\text { - } \mathrm{n}=210 \\
\text { Liver or General Medicine Clinics at } \\
\text { hospital of University of Michigan } \\
\text { - June 2002-August } 2003\end{array}$ & $70 / 78$ & $\begin{array}{l}\text { Risk of } \mathrm{HCC} \text { in obese patients vs control } \\
\text { OR: } 4.3 ; 95 \% \mathrm{Cl}: 2.1-8.4\end{array}$ \\
\hline $\begin{array}{l}\text { Polesel et al. } \\
\text { (2008) }\end{array}$ & Case-control & $\begin{array}{l}\text { - } \mathrm{n}=589 \\
\text { Province of Pordenone, Northeast } \\
\text { Italy, and in the town of Naples, } \\
\text { South Italy } \\
\text { - 1999-2003 }\end{array}$ & $185 / 119$ & $\begin{array}{l}\text { Risk of HCC obese vs control } \\
\text { OR: } 1.9 ; 95 \% \mathrm{Cl}: 0.9-3.9\end{array}$ \\
\hline $\begin{array}{l}\text { Ohishi et al. } \\
\text { (2008) }\end{array}$ & $\begin{array}{l}\text { Nested case- } \\
\text { control study }\end{array}$ & $\begin{array}{l}\text { - } \mathrm{n}=868 \\
\text { Japan }\end{array}$ & $224 / 163$ & $\begin{array}{l}\text { Risk of HCC obese vs nonobese } \\
\text { RR: } 4.36 ; 96 \% \text { Cl:1.48-13.0 }\end{array}$ \\
\hline
\end{tabular}

surveillance and those with such a low risk of HCC that inclusion in a surveillance program is deemed unnecessary. Liu et al. suggested that a $\mathrm{G}$ polymorphism in patatin-like phospholipase domain-containing 3, also called adiponutrin (PNPLA3) might be helpful, especially for identifying patients who may not need regular screening. In a case-control study of 100 European Caucasians with NAFLD-related HCC and 275 controls with NAFLD but without HCC, a clear association between HCC in NASH and PNPLA3 was demonstrated. The presence of each copy of the PNPLA3 rs738409 minor (G) allele resulted in a twofold increased risk of HCC (OR: 2.26; 95\% CI: 0.23-4.14) [49]. Another study revealed a strong association between the PNPLA3 rs738409 and the risk of HCC, particularly in patients with $\mathrm{HCV}$ [50].

Especially patients with a homozygous GG genotype of PNPLA3 have a higher risk to develop an HCC in comparison with patients with a homozygous CC or heterozygous CG genotype (adjusted OR of 3.21). Patients with a GG genotype and diabetes mellitus have an even higher risk to develop an HCC in comparison to the other genotypes (OR of 19,11) [51]. Replication of these findings is urgently needed and implementation with other parameters required allowing better HCC risk stratification.

\section{Treatments options}

There are several options available for treating HCC. It depends primarily on the stage of the disease, which is evaluated according three factors: the overall state of health of the patient assessed by the performance status; liver function assessed by the Child-Pugh score; and tumor burden. Resection is the therapy of choice for patients with good liver function, and is therefore always a first choice in patients without cirrhosis. If resection is not possible, patients may be considered for liver transplantation if they are within the Milano criteria [52]. Tumor ablation is another option, either instead of resection for small HCC or as bridging therapy for transplantation. When these curative options are not possible, patients receive palliative therapies. The two palliative options available are embolization 
and systemic targeted therapy. Since 2007, the only systemic targeted therapy reimbursed for the treatment of HCC has been sorafenib. Other drugs are being developed, with efficacy reported in 2017 from a Phase III study of firstline levantinib and a Phase III study of secondline regorafenib [53]; immuno-oncologic drugs also have potential to be used to treat patients with HCC in the future.
Generally, therapy options for HCC due to NASH and due to other etiologies of liver disease are the same. However, most patients with NASH have secondary diagnoses, which limit the treatment options, especially the option for surgery or transplantation. Most centers use Barcelona Liver Cancer Center stratification, which is based on the patient's performance status, the gravity of the cirrhosis assessed by

\section{Table 3. Studies showing the reduced risk of hepatocellular carcinoma with metformin use.}

\begin{tabular}{|c|c|c|c|c|}
\hline Study (year) & Design & Population & $\begin{array}{l}\text { Number of patients } \\
\text { with } \mathrm{HCC} / \text { diabetes/ } \\
\text { metformin }\end{array}$ & Key finding \\
\hline $\begin{array}{l}\text { Donadon et al. } \\
\text { (2009) }\end{array}$ & $\begin{array}{l}\text { Retrospective, } \\
\text { case-control }\end{array}$ & $\begin{array}{l}\text { - } n=465 \text { HCC, } n=618 \text { cirrothic } \\
\text { - } n=490 \text { control } \\
\text { - Caucasian } \\
\text { - Attending the Liver Unit and Diabetic } \\
\text { Clinic of 3rd Internal Medicine in the } \\
\text { Pordenone General Hospital (Pordenone, } \\
\text { Italy) } \\
\text { - January } 1994 \text { to June } 2006\end{array}$ & $465 / 351 / 87$ & $\begin{array}{l}\text { Metformin in HCC vs metformin in } \\
\text { control } \\
\text { OR: } 0.33 ; 95 \% \mathrm{Cl}: 0.1-0.7 \\
\mathrm{p}=0.0006\end{array}$ \\
\hline $\begin{array}{l}\text { Donadon et al. } \\
\text { (2010) }\end{array}$ & $\begin{array}{l}\text { Retrospective, } \\
\text { case-control }\end{array}$ & $\begin{array}{l}\text { - } \mathrm{n}=610 \mathrm{HCC}, \mathrm{n}=618, \mathrm{n}=1690 \text { control } \\
\text { Three groups of Caucasian individuals } \\
\text { Attending the 3rd Internal Medicine of the } \\
\text { Pordenone General Hospital (Pordenone, } \\
\text { Italy) } \\
\text { January } 1994 \text { to December } 2008 \text {. }\end{array}$ & $610 / 594 / 129$ & $\begin{array}{l}\text { Metformin in HCC vs metformin in } \\
\text { control } \\
\text { OR: } 0.33 ; 95 \% \mathrm{Cl}: 0.1-0.61 \\
\mathrm{p}=0.0005 \\
\text { Metformin in HCC vs metformin in liver } \\
\text { cirrhosis } \\
\text { OR: } 0.15 ; 95 \% \mathrm{Cl}: 0.09-0.28 ; \mathrm{p}<0.0001\end{array}$ \\
\hline $\begin{array}{l}\text { Hassan et al. } \\
(2010)\end{array}$ & Case-control & $\begin{array}{l}\text { - } \mathrm{n}=420 \mathrm{HCC}, \mathrm{n}=1104 \text { control } \\
\text { - Ongoing hospital-based case-control } \\
\text { study } \\
\text { - At the University of Texas M D Anderson } \\
\text { Cancer Center }\end{array}$ & $420 / 208 / 98$ & $\begin{array}{l}\text { Use of Biguanide or thiazolidinediones } \\
\text { in HCC vs control } \\
\text { OR: } 0.3 ; 95 \% \text { Cl: } 0.2-0.6 \\
p<0.001\end{array}$ \\
\hline $\begin{array}{l}\text { Nkontchou } \\
\text { et al. (2011) }\end{array}$ & $\begin{array}{l}\text { Prospective } \\
\text { cohort-study }\end{array}$ & $\begin{array}{l}\text { - } n=100 \text { diabetic patients } \\
\text { Ongoing HCV cirrhosis } \\
\text { - Screening program for HCC } \\
\text { - } 1988-2007\end{array}$ & $39 / 100 / 26$ & $\begin{array}{l}\text { Metformin treatment vs no treatment } \\
\text { Decrease in HCC occurrence } \\
\text { HR: } 0.19 ; 95 \% \text { Cl: } 0.04-0.79 \\
p=0.023\end{array}$ \\
\hline Lai et al. (2012) & $\begin{array}{l}\text { Retrospective } \\
\text { cohort study }\end{array}$ & $\begin{array}{l}\text { - } \mathrm{n}=19,349 \text { DM, } \mathrm{n}=77,396 \text { control } \\
\text { Taiwan National Health Insurance } \\
\text { Research Database } \\
\text { 2000-2005 }\end{array}$ & 679/19.349/16.282 & $\begin{array}{l}\text { HCC risk reduction in metformin use } \\
\text { vs nonuse } \\
\text { HR: } 0.49 ; 95 \% \mathrm{Cl}: 0.37-0.66\end{array}$ \\
\hline Seo et al. (2016) & $\begin{array}{l}\text { Retrospective } \\
\text { cohort study }\end{array}$ & $\begin{array}{l}\text { - } \mathrm{n}=5494 \mathrm{HCC} \\
\text { National Health Insurance Service and } \\
\text { Korea Center Cancer Registry }\end{array}$ & $5494 / 751 / 533$ & $\begin{array}{l}\text { Metformin use vs nonuse } \\
\text { Risk of mortality with an HR: } 0.38 ; 95 \% \\
\text { Cl: } 0.30-0.49 \text { and retreatment events } \\
\text { with an HR: } 0.41 ; 95 \% \text { Cl: } 0.33-0.52\end{array}$ \\
\hline
\end{tabular}


Table 4. Studies showing the reduced risk of hepatocellular carcinoma with statin use.

\begin{tabular}{|c|c|c|c|c|}
\hline $\begin{array}{l}\text { Study } \\
\text { (year) }\end{array}$ & Design & Population & $\begin{array}{l}\text { Number of } \\
\text { patients with } \\
\text { HCC/statin }\end{array}$ & Key finding \\
\hline $\begin{array}{l}\text { Friis et al. } \\
(2005)\end{array}$ & Cohort study & $\begin{array}{l}\text { - } \mathrm{n}=334,754 \\
\text { Patients with liver cancers } \\
\text { - Prescription Database of North Jutland } \\
\text { County and the Danish Cancer Registry } \\
\text { - } 1989-2002\end{array}$ & $171 / 12.251$ & $\begin{array}{l}\text { Statin users vs nonusers } \\
\text { Adjusted rate ration; } 1.16 ; 95 \% \mathrm{Cl}: 0.46-2.90\end{array}$ \\
\hline $\begin{array}{l}\text { El-Serag } \\
\text { et al. (2009) }\end{array}$ & Case-control & $\begin{array}{l}\text { - } \mathrm{n}=6515 \\
\text { Matched case-control study nested within a } \\
\text { cohort of patients with diabetes }\end{array}$ & $1303 / 3213$ & $\begin{array}{l}\text { Statin vs nonuse } \\
\text { Adjusted OR: } 0.74 ; 95 \% \mathrm{Cl}: 0.64-0.87\end{array}$ \\
\hline $\begin{array}{l}\text { Chiu et al. } \\
(2011)\end{array}$ & Case-control & $\begin{array}{l}\text { - } \mathrm{n}=2332 \\
\text { Data were retrospectively collected } \\
\text { - Taiwan National Health Insurance Research } \\
\text { Database } \\
\text { - } 2005-2008 \text {, age }>50 \text { years }\end{array}$ & $1166 / 312$ & $\begin{array}{l}\text { HCC vs control } \\
\text { OR: } 0.62 ; 95 \% \mathrm{Cl}: 0.45-0.83\end{array}$ \\
\hline $\begin{array}{l}\text { Tsan et al. } \\
(2012)\end{array}$ & Cohort study & & $1021 / 2785$ & $\begin{array}{l}\text { Statin use vs nonuse } \\
\text { Dose depending } \\
\text { HR: } 0.66 ; 95 \% \mathrm{Cl}: 0.44-0.99 ; 28-90 \text { cDDDs } \\
\text { HR: } 0.41 ; 95 \% \mathrm{Cl}: 0.27-0.61 ; 91-365 \text { CDDDs } \\
\text { HR: } 0.34 ; 95 \% \text { Cl: } 0.18-0.67 ;>365 \text { cDDDs }\end{array}$ \\
\hline $\begin{array}{l}\text { Singh et al. } \\
(2013)\end{array}$ & Meta-analysis & $\begin{array}{l}\text { - } \mathrm{n}=1,459,417 \\
\text { - Ten studies reporting } \\
\text { - Systemic review on Medline }\end{array}$ & $4298 /-$ & $\begin{array}{l}\text { Statin use vs nonuse } \\
\text { OR: } 0.63 ; 95 \% \mathrm{Cl}: 0.52-0.76\end{array}$ \\
\hline $\begin{array}{l}\text { Tsan et al. } \\
(2013)\end{array}$ & Cohort study & $\begin{array}{l}\text { - } \mathrm{n}=260,864 \\
\text { Population-based cohort study } \\
\text { - HCV-infected patients } \\
\text { - Taiwan National Health Insurance Research } \\
\text { Database } \\
\text { - } 1 \text { January } 1999-31 \text { December } 2010\end{array}$ & $27.883 / 35.023$ & $\begin{array}{l}\text { A dose-response relationship statin use and } \\
\text { nonuse } \\
\text { HR: } 0.66 ; 95 \% \mathrm{Cl}: 0.59-0.74 ; 28-89 \text { cDDDs } \\
\text { HR: } 0.47 ; 95 \% \mathrm{Cl}: 0.40-0.56 ; 90-180 \text { CDDDs } \\
\text { HR: } 0.33 ; 95 \% \mathrm{Cl}: 0.25-0.42 ; 180 \text { CDDDs }\end{array}$ \\
\hline $\begin{array}{l}\text { McGlynn } \\
\text { et al. (2014) }\end{array}$ & Case-control & $\begin{array}{l}\text { - } \mathrm{n}=562 \\
\text { Members of the Health Alliance Plan HMO of } \\
\text { the Henry Ford Health System } \\
\text { - } 1999-2010\end{array}$ & $94 / 258$ & $\begin{array}{l}\text { Ever use of statins vs nonuse } \\
\text { OR: } 0.32 ; 95 \% \mathrm{Cl}: 0.15-0.67\end{array}$ \\
\hline $\begin{array}{l}\text { McGlynn } \\
\text { et al. (2015) }\end{array}$ & Case-control & $\begin{array}{l}\text { - } \mathrm{n}=5835 \\
\text { United Kingdom's Clinical Practice Research } \\
\text { Data link } \\
\text { - Persons diagnosed with primary liver cancer } \\
\text { - } 1988-2011\end{array}$ & 1195/- & $\begin{array}{l}\text { Statin use vs nonuse } \\
\text { OR: } 0.55 ; 95 \% \mathrm{Cl}: 0.45-0.69\end{array}$ \\
\hline $\begin{array}{l}\text { Huang } \\
\text { et al. (2016) }\end{array}$ & Cohort study & $\begin{array}{l}\text { - } \mathrm{n}=13,086 \\
\text { Data from the Taiwanese National Health } \\
\text { Insurance Research Database } \\
\text { - } 1997-2009 \\
\text { - CHB patients }\end{array}$ & $314 / 6543$ & $\begin{array}{l}\text { Statin use vs nonuse } \\
p<0.001\end{array}$ \\
\hline $\begin{array}{l}\text { Kim et al. } \\
(2017)\end{array}$ & Case-control & $\begin{array}{l}\text { - } \mathrm{n}=2519 \text { patients } \\
\text { - Diabetes } \\
\text { - Korea }\end{array}$ & $229 / 405$ & $\begin{array}{l}\text { Statin use vs nonuse } \\
\text { OR: } 0.36 ; 95 \% \mathrm{Cl}: 0.22-0.60\end{array}$ \\
\hline
\end{tabular}


the Child-Pugh score and the tumor burden. However, several considerations are specific for patients with NASH-induced HCC. If approximately $75 \%$ of patients with HCC due to alcohol or to $\mathrm{CHC}$ have cirrhosis, the percentage of NASH-induced HCC is much lower at 50\%, as demonstrated by Paradis, and confirmed through many reports from Asia, Europe and the USA [55]. Patients with NASH-induced HCC without cirrhosis are considered for curative surgery more frequently than patients with HCC due to other etiologies. However, these patients should be selected carefully, as they tend to be older and more frequently have comorbidities, such as diabetes mellitus and obesity, and are prone to cardiovascular events. Interestingly, steatosis by itself has been suggested to be associated with more local complications after resection [56]. Therefore, the decision to perform curative surgery should take into account these factors, which will increase the risk of complications.

\section{Prevention of risk factors with drugs}

Patients with NASH often also have metabolic syndrome, obesity, diabetes mellitus and atherosclerosis. Consequently, treatments for these comorbidities - metformin, statins and aspirin - may attenuate their HCC risk.

Regarding thiazolidinediones (TZDs), there is also a recent study from Huang et al., which showed that their use might reduce the incidence of HCC. They compared a group with patients with newly diagnosed diabetes and using TZD with a group without using TZDs and newly diagnosed diabetes mellitus. The HR was
0.53 (95\% CI: $0.38-0.77)$. In this review we focused on the first-line therapies because most of the patients with newly diagnosed/suspected NAFLD normally present in the outpatient clinic with already aspirin, statin or metformin on their medication list [57].

\section{- Metformin}

Metformin has been shown as a preventive factor in developing HCC (Table 3). Experimental data suggest that metformin might have a protective effect against HCC. In a mouse model, it was demonstrated that metformin inhibits the 'de novo lipogenesis' in hepatocytes [58], and in another model of mice with HCC, it also had growth inhibitory and immune-modulatory effects [59]. Several publications document that the use of metformin reduces the risk of HCC in humans, in contrast to insulin-containing regimens. Four case-control studies found a reduced risk of developing HCC in patients with diabetes treated with metformin (Table 1). In two studies, treatment with metformin was associated with between 67 and $85 \%$ reduced risk of HCC in patients with diabetes $[60,61]$. In a case-control study, a 7\% reduced risk of developing HCC was attributed to each years of metformin use in patients with diabetes and liver disease; the decreased risk was shown to occur in a dosedependent manner [62]. Several cohort studies support the link between HCC incidence and metformin intake. A prospective cohort study demonstrated that metformin was independently associated with a $81 \%$ reduced risk of HCC in patients with CHC and diabetes mellitus [63]. Metformin use was also associated with

Table 5. Studies showing the reduced risk of hepatocellular carcinoma, with aspirin use.

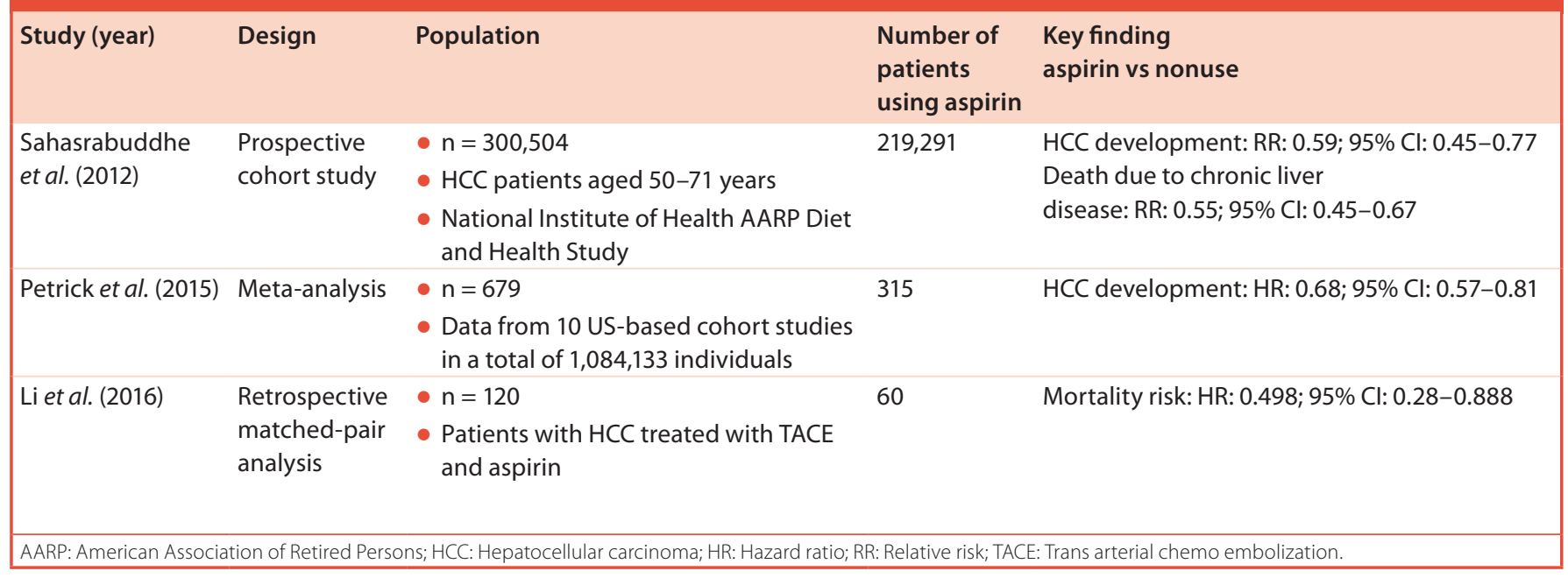


a $62 \%$ reduced risk of HCC-specific mortality, and a $59 \%$ reduced risk of retreatment events in a group of patients with HCC and diabetes mellitus after treatment with curative hepatic resection [64].

In contrast to the abovementioned studies, Kawaguchi et al. observed an increased risk of HCC due to insulin treatment in a case-control study in Japanese patients with CHC and diabetes [65]. In addition, this was supported by the findings from a study by Hassan et al., who showed an increasing incidence of HCC with insulin treatment, although they also showed a $70 \%$ risk reduction for patients treated with biguanides or TZDs [18].

\section{- Statins}

Statin is also shown to have a protective effect in preventing HCC (Table 4). A populationbased cohort study, which used registry data (1989-2002) from Danish patients with liver cancers, demonstrated a slightly reduced cancer incidence in individuals taking a statin [66]. Five case-control studies provide support for a reduced risk of developing HCC with regular intake of a statin (Table 2). A recent case-control study showed that by taking a statin, the risk of HCC development in patients with diabetes mellitus who might develop HCC due to a liver disease could be reduced by $64 \%$ [67]. In another two studies, in which patients have a low risk of HCC, again, the risk of developing of HCC was reduced with statin use $[68,69]$. The risk of HCC was also shown to be dose dependent [70]. El-Serag et al. also observed a significant reduction in risk of developing an HCC by using a statin in a case-control study [71]. These data are further supported by data from cohort studies demonstrating the reduced risk of HCC in statin users compared with nonusers. Tsan et al. demonstrated the association between statin use and reduction of $\mathrm{HCC}$ risk in a group of patients with $\mathrm{CHB}$ and $\mathrm{CHC}[72,73]$. A population-based cohort study showed a significantly lower cumulative incidence of cirrhosis in patients using statin (RR: 0.433; 95\% CI: 0.344-0.515; modified log-rank test; $\mathrm{p}<0.001)$ and decompensated cirrhosis (RR: 0.468; 95\% CI: 0.344-0.637; $\mathrm{p}<0.001)$ compared with patients not using statins [74]. The reduced risk of HCC by using a statin is supported by data from a meta-analysis in Asian and western populations [75]. These findings would be further strengthened by supportive prospective data, although there is a current lack of prospective data, especially in patients with NASH.

\section{- Aspirin}

A connection between COX and cancer genesis has been suggested and this is supported by literature on the positive effect COX-inhibitors have on the reduced risk of developing cancer (Table 5) [76]. It is already known that the risk of developing colorectal cancer is reduced with daily aspirin use [77]. Experimental data have suggested a positive effect of aspirin on the outcome of liver disease and how it might be used to reduce the risk of developing HCC $[78,79]$. One of the proposed mechanisms for this positive effect is a modification of the lipid metabolism by aspirin [80]. Meta-analysis has shown that the daily use of aspirin may reduce HCC risk by $32 \%$ [81]. Few clinical trials have investigated the association between aspirin use and reduction in HCC risk. One reason for this could be that it is difficult to find patients with NASH who only take aspirin without statin or metformin therapy.

\section{Conclusion}

The hepatology community will be faced with many important challenges over the next few years, with liver specialists likely to encounter a greater number of patients with NASH-induced HCC, and so they will need to be aware as to the most appropriate management of this population. These patients have specific features and characteristics - including older age and more co-morbidities compared with patients with $\mathrm{HCV}$ - or hepatitis $\mathrm{B}$ virus-induced $\mathrm{HCC}$ - which have to be taken into account to provide the best therapeutic plan. Adding to the challenge is that these HCCs arise often in a noncirrhotic liver rendering surgery more attractive, but early detection by screening more difficult.

\section{Future perspective}

It is expected that there will be an approved medication for the treatment of NASH in the next years. Several registry Phase III trials are ongoing testing elafibranor, obeticholic acid, selonsertib and cenicriviroc. Nevertheless, lifestyle modifications will remain the first line in the management of these patients. Both approaches are expected to curb the risk to develop HCC. The identification of the population at risk for HCC and which need to be enrolled in a surveillance program is one of the big challenges for the next years in the field of NAFLD/NASH. 
Financial \& competing interests disclosure JF Dufour is on the advisory committees of Abbvie, Bayer, BMS, Falk, Genfit, Gilead Science, Intercept, Lilly, Merck and Novartis. JF Dufour has received speaking and teaching fees from Abbvie, Bayer, BMS, Genfit, Gilead Science and Novartis. He has also received an unrestricted research grant from Bayer. The authors have no other relevant affiliations or financial involvement with any organization or entity with a financial interest in or financial conflict with the subject matter or materials discussed in the manuscript apart from those disclosed.

No writing assistance was utilized in the production of this manuscript.

\section{References}

1 Bosetti C, Turati F, La Vecchia C. Hepatocellular carcinoma epidemiology. Best Pract. Res. Clin. Gastroenterol. 28(5), 753-770 (2014)

2 Hashim D, Boffetta P, La Vecchia C et al. The global decrease in cancer mortality: trends and disparities. Ann. Oncol. 27(5), 926-933 (2016).

3 Bertuccio P, Turati F, Carioli G et al. Global trends and predictions in hepatocellular carcinoma mortality. J. Hepatol. 67(2), 302-309 (2017)

4 Goldberg D, Ditah IC, Saeian Ket al. Changes in the prevalence of hepatitis $\mathrm{C}$ virus infection, nonalcoholic steatohepatitis, and alcoholic liver disease among patients with cirrhosis or liver failure on the waitlist for liver transplantation. Gastroenterology 152(5), 1090.e1091-1099.e1091 (2017).

5 Wong RJ, Cheung R, Ahmed A. Nonalcoholic steatohepatitis is the most rapidly growing indication for liver transplantation in patients with hepatocellular carcinoma in the US. Hepatology 59(6), 2188-2195 (2014).

6 Wong RJ, Aguilar M, Cheung R et al. Nonalcoholic steatohepatitis is the second leading etiology of liver disease among adults awaiting liver transplantation in the United States. Gastroenterology 148(3), 547-555 (2015).

7 Flemming JA, Kim WR, Brosgart CL, Terrault NA. Reduction in liver transplant wait-listing in the era of direct-acting antiviral therapy. Hepatology 65(3), 804-812 (2017).

8 Zoller $\mathrm{H}$, Tilg $\mathrm{H}$. Nonalcoholic fatty liver disease and hepatocellular carcinoma. Metabolism 65(8), 1151-1160 (2016).

9 Schulze K, Imbeaud S, Letouze E et al. Exome sequencing of hepatocellular carcinomas identifies new mutational signatures and potential therapeutic targets. Nat. Genet. 47(5), 505-511 (2015).

10 Tannapfel A, Denk H, Dienes HP et al. Histopathological diagnosis of non-alcoholic and alcoholic fatty liver disease. Virchows Arch. 458(5), 511-523 (2011).
11 Hashimoto E, Tokushige K. Hepatocellular carcinoma in non-alcoholic steatohepatitis: growing evidence of an epidemic? Hepatol. Res. 42(1), 1-14 (2012).

12 Dyson J, Jaques B, Chattopadyhay D et al. Hepatocellular cancer: the impact of obesity, Type 2 diabetes and a multidisciplinary team. J. Hepatol. 60 (1), 110-117 (2014).

13 Welzel TM, Graubard BI, Zeuzem S, El-Serag HB, Davila JA, McGlynn KA. Metabolic syndrome increases the risk of primary liver cancer in the United States: a study in the SEER-Medicare database. Hepatology 54(2), 463-471 (2011).

14 Turati F, Talamini R, Pelucchi C et al. Metabolic syndrome and hepatocellular carcinoma risk. Br. J. Cancer 108(1), 222-228 (2013).

15 Chen CL, Yang HI, Yang WS et al. Metabolic factors and risk of hepatocellular carcinoma by chronic hepatitis $\mathrm{B} / \mathrm{C}$ infection: a follow-up study in Taiwan. Gastroenterology 135(1), 111-121 (2008).

16 Adami HO, Chow WH, Nyren O et al. Excess risk of primary liver cancer in patients with diabetes mellitus. J. Natl Cancer Inst. 88(20), 1472-1477 (1996).

17 El-Serag HB, Tran T, Everhart JE. Diabetes increases the risk of chronic liver disease and hepatocellular carcinoma. Gastroenterology 126(2), 460-468 (2004)

18 Hassan MM, Curley SA, Li D et al. Association of diabetes duration and diabetes treatment with the risk of hepatocellular carcinoma. Cancer 116(8), 1938-1946 (2010).

19 Davila JA, Morgan RO, Shaib Y, McGlynn KA, El-Serag HB. Diabetes increases the risk of hepatocellular carcinoma in the United States: a population based case control study. Gut 54(4), 533-539 (2005).

20 Koh WP, Wang R, Jin A, Yu MC, Yuan JM. Diabetes mellitus and risk of hepatocellular carcinoma: findings from the Singapore Chinese Health Study. Br. J. Cancer 108(5), 1182-1188 (2013).

21 Veldt BJ, Chen W, Heathcote EJ et al. Increased risk of hepatocellular carcinoma among patients with hepatitis $\mathrm{C}$ cirrhosis and diabetes mellitus. Hepatology 47(6), 1856-1862 (2008).

22 Li X, Xu H, Gao Y, Pan M, Wang L, Gao P. Diabetes mellitus increases the risk of hepatocellular carcinoma in treatment-naive chronic hepatitis $\mathrm{C}$ patients in China. Medicine (Baltimore) 96(13), e6508 (2017)

23 Desbois AC, Cacoub P. Diabetes mellitus, insulin resistance and hepatitis $\mathrm{C}$ virus infection: a contemporary review. World J. Gastroenterol. 23(9), 1697-1711 (2017).

24 Bose SK, Ray R. Hepatitis C virus infection and insulin resistance. World J. Diabetes 5(1), 52-58 (2014).

25 Wang C, Wang X, Gong G et al. Increased risk of hepatocellular carcinoma in patients with diabetes mellitus: a systematic review and meta-analysis of cohort studies. Int. J. Cancer 130 (7), 1639-1648 (2012).

26 Su YW, Liu PH, Hsu CY et al. Prognostic impact of diabetes mellitus on hepatocellular carcinoma: special emphasis from the BCLC perspective. PLoS ONE 12(3), e0174333 (2017).

27 Moller H, Mellemgaard A, Lindvig K, Olsen $\mathrm{JH}$. Obesity and cancer risk: a Danish record-linkage study. Eur. J. Cancer 30A(3), 344-350 (1994).

28 Samanic C, Gridley G, Chow WH, Lubin J, Hoover RN, Fraumeni JF, Jr. Obesity and cancer risk among white and black United States veterans. Cancer Causes Control 15(1), 35-43 (2004).

29 Pan SY, Johnson KC, Ugnat AM, Wen SW, Mao Y, Canadian Cancer Registries Epidemiology Research G. Association of obesity and cancer risk in Canada. Am. J. Epidemiol. 159(3), 259-268 (2004).

30 Kuriyama S, Tsubono Y, Hozawa A et al. Obesity and risk of cancer in Japan. Int. J. Cancer 113(1), 148-157 (2005).

31 Jee SH, Yun JE, Park EJ et al. Body mass index and cancer risk in Korean men and women. Int. J. Cancer 123(8), 1892-1896 (2008).

32 Renehan AG, Tyson M, Egger M, Heller RF, Zwahlen M. Body-mass index and incidence 
of cancer: a systematic review and metaanalysis of prospective observational studies. Lancet 371(9612), 569-578 (2008).

33 Nair S, Mason A, Eason J, Loss G, Perrillo RP. Is obesity an independent risk factor for hepatocellular carcinoma in cirrhosis? Hepatology 36(1), 150-155 (2002).

34 Marrero JA, Fontana RJ, Fu S, Conjeevaram HS, Su GL, Lok AS. Alcohol, tobacco and obesity are synergistic risk factors for hepatocellular carcinoma. J. Hepatol. 42(2), 218-224 (2005).

35 Polesel J, Zucchetto A, Montella M et al. The impact of obesity and diabetes mellitus on the risk of hepatocellular carcinoma. Ann. Oncol. 20(2), 353-357 (2009).

36 Ohishi W, Fujiwara S, Cologne JB et al. Risk factors for hepatocellular carcinoma in a Japanese population: a nested case-control study. Cancer Epidemiol. Biomarkers Prev. 17(4), 846-854 (2008).

37 Saunders D, Seidel D, Allison M, Lyratzopoulos G. Systematic review: the association between obesity and hepatocellular carcinoma - epidemiological evidence. Aliment. Pharmacol. Ther. 31(10), 1051-1063 (2010).

38 Ohki T, Tateishi R, Shiina S et al. Visceral fat accumulation is an independent risk factor for hepatocellular carcinoma recurrence after curative treatment in patients with suspected NASH. Gut 58(6), 839-844 (2009).

39 Berentzen TL, Gamborg M, Holst C, Sorensen TI, Baker JL. Body mass index in childhood and adult risk of primary liver cancer. J. Hepatol. 60(2), 325-330 (2014).

40 Schlesinger S, Aleksandrova K, Pischon T et al. Abdominal obesity, weight gain during adulthood and risk of liver and biliary tract cancer in a European cohort. Int. J. Cancer 132(3), 645-657 (2013).

41 Hassan MM, Abdel-Wahab R, Kaseb A et al. Obesity early in adulthood increases risk but does not affect outcomes of hepatocellular carcinoma. Gastroenterology 149(1), 119-129 (2015).

42 Hagstrom H, Tynelius P, Rasmussen F. High $\mathrm{BMI}$ in late adolescence predicts future severe liver disease and hepatocellular carcinoma: a national, population-based cohort study in 1.2 million men. Gut doi:10.1136/ gutjnl-2016-313622 (2017) (Epub ahead of print).

43 Calle EE, Rodriguez C, Walker-Thurmond K, Thun MJ. Overweight, obesity, and mortality from cancer in a prospectively studied cohort of US adults. N. Engl. J. Med. 348(17), 1625-1638 (2003).
44 Batty GD, Shipley MJ, Jarrett RJ, Breeze E, Marmot MG, Smith GD. Obesity and overweight in relation to organ-specific cancer mortality in London (UK): findings from the original Whitehall study. Int. J. Obes. (Lond.) 29(10), 1267-1274 (2005).

45 Leung C, Yeoh SW, Patrick D et al. Characteristics of hepatocellular carcinoma in cirrhotic and non-cirrhotic non-alcoholic fatty liver disease. World J. Gastroenterol. 21(4), 1189-1196 (2015).

46 Piscaglia F, Svegliati-Baroni G, Barchetti A et al. Clinical patterns of hepatocellular carcinoma in nonalcoholic fatty liver disease: a multicenter prospective study. Hepatology 63(3), 827-838 (2016)

47 Takuma Y, Nouso K. Nonalcoholic steatohepatitis-associated hepatocellular carcinoma: our case series and literature review. World J. Gastroenterol. 16(12), 1436-1441 (2010).

48 Younossi ZM, Otgonsuren M, Henry L et al. Association of nonalcoholic fatty liver disease (NAFLD) with hepatocellular carcinoma (HCC) in the United States from 2004 to 2009. Hepatology 62(6), 1723-1730 (2015).

49 Liu YL, Patman GL, Leathart JB et al. Carriage of the PNPLA3 rs738409 C > G polymorphism confers an increased risk of non-alcoholic fatty liver disease associated hepatocellular carcinoma. J. Hepatol. 61(1), 75-81 (2014).

50 Balasus D, Way M, Fusilli C et al. The association of variants in PNPLA3 and GRP78 and the risk of developing hepatocellular carcinoma in an Italian population. Oncotarget 7(52), 86791-86802 (2016).

51 Hassan MM, Kaseb A, Etzel CJ et al. Genetic variation in the PNPLA3 gene and hepatocellular carcinoma in USA: risk and prognosis prediction. Mol. Carcinog. 52(Suppl. 1), E139-E147 (2013).

52 Mazzaferro V, Regalia E, Doci R et al. Liver transplantation for the treatment of small hepatocellular carcinomas in patients with cirrhosis. N. Engl. J. Med. 334(11), 693-699 (1996).

53 Bruix J, Qin S, Merle P et al. Regorafenib for patients with hepatocellular carcinoma who progressed on sorafenib treatment (RESORCE): a randomised, double-blind, placebo-controlled, Phase III trial. Lancet 389(10064), 56-66 (2017).

54 Forner A, Llovet JM, Bruix J. Hepatocellular carcinoma. Lancet 379(9822), 1245-1255 (2012).

55 Paradis V, Zalinski S, Chelbi E et al. Hepatocellular carcinomas in patients with metabolic syndrome often develop without significant liver fibrosis: a pathological analysis. Hepatology 49(3), 851-859 (2009).

56 Kurmann A, Wanner B, Martens F et al. Hepatic steatosis is associated with surgicalsite infection after hepatic and colorectal surgery. Surgery 156(1), 109-116 (2014).

57 Huang MY, Chung CH, Chang WK et al. The role of thiazolidinediones in hepatocellular carcinoma risk reduction: a population-based cohort study in Taiwan. Am. J. Cancer Res. 7(7), 1606-1616 (2017).

58 Ford RJ, Fullerton MD, Pinkosky SL et al. Metformin and salicylate synergistically activate liver AMPK, inhibit lipogenesis and improve insulin sensitivity. Biochem. J. 468(1), 125-132 (2015).

59 Zhao D, Long XD, Lu TF et al. Metformin decreases IL-22 secretion to suppress tumor growth in an orthotopic mouse model of hepatocellular carcinoma. Int. J. Cancer 136(11), 2556-2565 (2015).

60 Donadon V, Balbi M, Ghersetti M et al. Antidiabetic therapy and increased risk of hepatocellular carcinoma in chronic liver disease. World J. Gastroenterol. 15(20), 2506-2511 (2009).

61 Donadon V, Balbi M, Mas MD et al. Metformin and reduced risk of hepatocellular carcinoma in diabetic patients with chronic liver disease. Liver Int. 30 (5), 750-758 (2010).

62 Chen HP, Shieh JJ, Chang CC et al. Metformin decreases hepatocellular carcinoma risk in a dose-dependent manner: population-based and in vitro studies. Gut 62(4), 606-615 (2013).

63 Nkontchou G, Cosson E, Aout M et al. Impact of metformin on the prognosis of cirrhosis induced by viral hepatitis $\mathrm{C}$ in diabetic patients. J. Clin. Endocrinol. Metab. 96(8), 2601-2608 (2011).

64 Seo YS, Kim YJ, Kim MS et al. Association of metformin use with cancer-specific mortality in hepatocellular carcinoma after curative resection: a nationwide population-based study. Medicine (Baltimore) 95(17), e3527 (2016).

65 Kawaguchi T, Taniguchi E, Morita Y et al. Association of exogenous insulin or sulphonylurea treatment with an increased incidence of hepatoma in patients with hepatitis C virus infection. Liver Int. 30 (3), 479-486 (2010).

66 Friis S, Poulsen AH, Johnsen SP et al. Cancer risk among statin users: a population-based cohort study. Int. J. Cancer 114(4), 643-647 (2005). 
67 Kim G, Jang SY, Han E et al. Effect of statin on hepatocellular carcinoma in patients with Type 2 diabetes: A nationwide nested casecontrol study. Int. J. Cancer 140(4), 798-806 (2017).

68 McGlynn KA, Divine GW, Sahasrabuddhe VV et al. Statin use and risk of hepatocellular carcinoma in a US population. Cancer Epidemiol. 38(5), 523-527 (2014).

69 McGlynn KA, Hagberg K, Chen J et al. Statin use and risk of primary liver cancer in the Clinical Practice Research Datalink. J. Natl Cancer Inst. 107(4), pii:djv009 (2015) (Epub ahead of print).

70 Chiu HF, Ho SC, Chen CC, Yang CY. Statin use and the risk of liver cancer: a populationbased case-control study. Am. J. Gastroenterol. 106(5), 894-898 (2011).

71 El-Serag HB, Johnson ML, Hachem C, Morgana RO. Statins are associated with a reduced risk of hepatocellular carcinoma in a large cohort of patients with diabetes. Gastroenterology 136(5), 1601-1608 (2009).

72 Tsan YT, Lee CH, Ho WC, Lin MH, Wang JD, Chen PC. Statins and the risk of hepatocellular carcinoma in patients with hepatitis C virus infection. J. Clin. Oncol. 31(12), 1514-1521 (2013).

73 Tsan YT, Lee CH, Wang JD, Chen PC. Statins and the risk of hepatocellular carcinoma in patients with hepatitis B virus infection. J. Clin. Oncol. 30(6), 623-630 (2012).
74 Huang YW, Lee CL, Yang SS et al. Statins reduce the risk of cirrhosis and its decompensation in chronic hepatitis $\mathrm{b}$ patients: a nationwide cohort study. Am. J. Gastroenterol. 111(7), 976-985 (2016).

75 Singh S, Singh PP, Singh AG, Murad MH, Sanchez W. Statins are associated with a reduced risk of hepatocellular cancer: a systematic review and meta-analysis. Gastroenterology 144(2), 323-332 (2013).

76 Madrigal-Perez VM, Garcia-Rivera A, Rodriguez-Hernandez A et al. Preclinical analysis of nonsteroidal anti-inflammatory drug usefulness for the simultaneous prevention of steatohepatitis, atherosclerosis and hyperlipidemia. Int. J. Clin. Exp. Med. 8(12), 22477-22483 (2015).

77 Garcia-Albeniz X, Chan AT. Aspirin for the prevention of colorectal cancer. Best Pract. Res. Clin. Gastroenterol. 25(4-5), 461-472 (2011).

78 Iannacone M, Sitia G, Narvaiza I, Ruggeri ZM, Guidotti LG. Antiplatelet drug therapy moderates immune-mediated liver disease and inhibits viral clearance in mice infected with a replication-deficient adenovirus. Clin. Vaccine Immunol. 14(11), 1532-1535 (2007).

79 Sitia G, Aiolfi R, Di Lucia P et al. Antiplatelet therapy prevents hepatocellular carcinoma and improves survival in a mouse model of chronic hepatitis B. Proc. Natl Acad. Sci. USA 109(32), E2165-E2172 (2012).
80 Yang G, Wang Y, Feng J et al. Aspirin suppresses the abnormal lipid metabolism in liver cancer cells via disrupting an NFkappaB-ACSL1 signaling. Biochem. Biophys. Res. Commun. 486(3), 827-832 (2017).

81 Petrick JL, Sahasrabuddhe VV, Chan AT et $a l$. NSAID use and risk of hepatocellular carcinoma and intrahepatic cholangiocarcinoma: The Liver Cancer Pooling Project. Cancer Prev. Res. (Phila) 8(12), 1156-1162 (2015).

82 Singh S, Singh PP, Singh AG, Murad MH, Sanchez W. Anti-diabetic medications and the risk of hepatocellular cancer: a systematic review and meta-analysis. $A m$. J. Gastroenterol. 108(6), 881-891; quiz 892 (2013).

83 Lai SW, Chen PC, Liao KF, Muo CH, Lin CC, Sung FC. Risk of hepatocellular carcinoma in diabetic patients and risk reduction associated with anti-diabetic therapy: a population-based cohort study. Am. J. Gastroenterol. 107(1), 46-52 (2012).

84 Sahasrabuddhe VV, Gunja MZ, Graubard BI et al. Nonsteroidal anti-inflammatory drug use, chronic liver disease, and hepatocellular carcinoma. J. Natl Cancer Inst. 104(23), 1808-1814 (2012).

85 Li JH, Wang Y, Xie XY et al. Aspirin in combination with TACE in treatment of unresectable HCC: a matched-pairs analysis. Am. J. Cancer Res. 6(9), 2109-2116 (2016). 
REVIEW Klein \& Dufour 
REVIEW Klein \& Dufour 